\title{
Caries experience and salivary aspects in individuals with fragile $X$ syndrome
}

\section{Cristhiane Olívia Ferreira do AMARAL ${ }^{\text {(a) }}$}

Fabiana Gouveia STRAIOTO(a) Marcelo Henrique NAPIMOGA ${ }^{(b)}$ Elizabeth Ferreira MARTINEZ(c)

\footnotetext{
(a) Universidade do Oeste Paulista UNOESTE, Department of Special Care Dentistry, Dental School, Presidente Prudente, SP, Brazil.

(b) São Leopoldo Mandic Institute and Research Center, Laboratory of Immunology and Molecular Biology, Campinas, SP, Brazil.

(c)São Leopoldo Mandic Institute and Research Center, Departament of Oral Pathology, Campinas, SP, Brazil.
}

\begin{abstract}
Fragile X syndrome (FXS) is the most common cause of hereditary mental retardation, but studies on the oral health condition of these patients are rare. The aim of this study was to determine the experience of dental caries in individuals with FXS, by examining the saliva profile, oral hygiene, socioeconomic characteristics and use of controlled drugs in these patients. Dental health was estimated using the decayed, missing and filled teeth index (DMF-T) and sialometry, and the $\mathrm{pH}$ value and buffering capacity of the saliva, colony forming units of S. mutans (CFU/mL), visible biofilm index, and socioeconomic status were all examined. The sample, comprising 23 individuals, had an average age of $17.3 \pm 5.6$ years, a DMF-T index of 5.5, a diminished salivary flow (78.3\%), and a low (73.9\%) saliva buffering capacity. Most (52.2\%) individuals presented with a high abundance (CFU/mL) of $S$. mutans. The experience of caries was correlated with salivary parameters, poor oral hygiene, lower socioeconomic status and an increased count of $S$. mutans in saliva.
\end{abstract}

Keywords: Fragile X Syndrome; Oral Health; Dental Caries; Saliva.

\section{Introduction}

Declaration of Interest: The authors certify that they have no commercial or associative interest that represents a conflict of interest in connection with the manuscript.

Corresponding author:

Cristhiane Oliva Ferreira do Amaral

E-mail: crisamaral@unoeste.br

htrps://doi.org/10.1590/1807-3107BOR-2017.vol31.0079

Submitted: Jan 18, 2017

Accepted for publication: July 10, 2017

Last revision: Aug 14, 2017
Fragile X syndrome (FXS), also known as Martin-Bell syndrome, is the most common inherited cause of mental impairment and is considered the second genetic etiology. The bearers of this syndrome, in addition to systemic impairments, can manifest behavioral problems, learning difficulties, and emotional and mental deficiencies., ${ }^{1,2,3}$

This syndrome is related to a mutation on the $X$ chromosome, in the Fragile X Mental Retardation 1 gene (FMR-1), which can be identified microscopically by a constriction called a 'fragile site' on the long arm of chromosome $\mathrm{X}$ and is associated with mechanisms of genetic inheritance that are not usually correlated with phenotypic abnormalities. ${ }^{4,5}$ Unlike Down syndrome, which does not tend to repeat itself in families, FXS has a high risk of familial occurrence in brothers. It is a dominant inheritance disorder linked to chromosome $\mathrm{X}^{3}$

The prevalence of this syndrome is controversial in the literature, with most authors reporting it as having a prevalence of 1:6,000 to 8,000 in women and 1:4,000 in men. ${ }^{6}$ Other studies have reported a prevalence of 1:2,000 in men and 1:4.000 in women worldwide. ${ }^{4}$ Furthermore, Waddell et al. ${ }^{7}$ estimated the prevalence of FXS as approximately 1 in 3,600 births. 
Some physical characteristics of FXS are easily detectable, including the following: an elongated face and ears and prominent forehead, hyperextended joints, strabismus, pectus excavatum, an increase in the volume of the testes (macroorchidism) and mitral valve prolapse. Common behavioral and systemic changes include the following: the presence of seizures, mental retardation, autism spectrum disorder (e.g., poor eye contact, speech, sensory hypersensitivity, and stereotyped or repetitive motor behaviors) ${ }^{8}$ and hyperactivity disorder. ${ }^{9}$ Oral features include a narrow and deep palate, mandibular prognathism, macroglossia, poor oral hygiene, enamel hypoplasia, malocclusion, presence of biofilm, dental caries, dental calculus and gingivitis. ${ }^{10}$

Mental deficiency and behavioral characteristics are factors that hinder the dental care for these patients because cognitive deficits, autism, hyperactivity and anxiety disorders may require multidisciplinary attention. ${ }^{8,11}$ In this way, patients with various syndromes, particularly those who experience neuropsychomotor development delay, can be considered at high risk for tooth decay and other oral diseases. . $^{10,12,13}$

Oral condition studies and studies on dental treatment characteristics of patients with FXS are rare, so it is believed that the dental needs of these patients have not been met, are related to poor hygiene, and are reinforced by salivary characteristics, the socioeconomic means of the patients, and the use of controlled drugs, such as anticonvulsants and antianxiety drugs, which cause hyposalivation and predispose the patient to oral diseases. ${ }^{14}$

Several authors have verified correlations among salivary flow, $\mathrm{pH}$, buffering capacity, cariogenic bacteria and caries experience in different groups of patients, both healthy and systemically compromised; however, these characteristics have not yet been studied in FXS. ${ }^{15,16,17,18,19,20,21}$ Disparities in oral health are found between the general population and people with low socioeconomic status and cultural barriers as well as people with disabilities. Several studies have verified the correlation between low socioeconomic status and increased caries experience, so it was necessary to investigate this correlation in individuals with FXS. ${ }^{22,23,24,25}$
The aim of this study was to verify the experience of dental caries in individuals with FXS, in correlation with the saliva profile, Streptococcus mutans, dental hygiene, the relationship between salivary and socioeconomic characteristics, and the use of controlled drugs in these patients.

\section{Materials and methods}

\section{Study population}

This study was approved by the Ethics and Research Committee under opinion 643.617. The parents or guardians of the patients who participated in this research were informed of the purpose of the study and agreed to participate by signing a form to acknowledge their informed consent. A nonrandom (convenience) sample was used, comprising all patients who presented with FXS and frequented the regional centers for dental care for patients with special needs in the city of Presidente Prudente, SP, and the surrounding region. The inclusion criteria for patients were as follows: the confirmation of FXS with molecular tests, no other syndromes associated with FXS and no use of antimicrobials at the time the research was conducted. A total of 23 carriers of FXS of both genders, 18 male and 5 female and aged between 12 and 25 years, participated in this research.

\section{Evaluation of socioeconomic status}

The questionnaire for socioeconomic evaluation consisted of five questions related to socioeconomic variables to classify patients into different social classes. The five factors were monthly family income, number of people in the family, educational level, the ownership of the residential address, and the professions of the parents. These variables were given scores and were analyzed for subsequent classification. Every answer was assigned a proportional weight in the overall evaluation. The summed total of points was a single score, ranging from 0 to 10 , classifying the patients into the following five levels: low: 1-2.9; medium-low: 3-4.9; medium: 5-6.9; medium-high: 7-8.9 and high: $9-10 .{ }^{26}$

\section{Oral dental physical examination}

A previously calibrated evaluator responsible for determining the rate of tooth decay was used for the 
DMF-T index, aiming to assess the past and present history of dental caries in patients. ${ }^{27}$ This index was also used to evaluate the amount of visible biofilm on the surfaces of the teeth ${ }^{28}$, which was assigned the following scores: 0 -absence of visible biofilm; 1-thin biofilm presence only on anterior teeth, 2-presence of thin biofilm distributed on anterior and posterior teeth, 3-thick biofilm presence only on anterior or posterior teeth, 4-presence of thick biofilm on anterior teeth and thin on posterior teeth (or vice versa), and 5-the presence of thick biofilm on posterior teeth and anterior teeth.

\section{Saliva collection for determination of salivary flow, $\mathrm{pH}$, buffering capacity}

The total saliva collection, stimulated for the determination of salivary flow, $\mathrm{pH}$, and buffering capacity, was performed between 8:30 and 11:30 in the morning (to minimize the effect of circadian rhythm) and 2 hours after food intake and tooth brushing. The saliva was collected for five minutes without prior stimulation, by moving a saliva ejector evenly around the oral vestibule and on the floor of the mouth with a special disposable sialometer, which was composed of a polystyrene tube with millimeter markings $(15 \mathrm{~mL})$. The tube was sealed after two saliva ejectors (Figure 1). ${ }^{29,30}$

The rate of salivary flow was considered to be lessened when below $0.3 \mathrm{~mL}$ and normal when above $0.3 \mathrm{~mL} .{ }^{31}$ The container holding the saliva was sealed to prevent release of $\mathrm{CO}_{2}$ and any $\mathrm{pH}$ changes, and

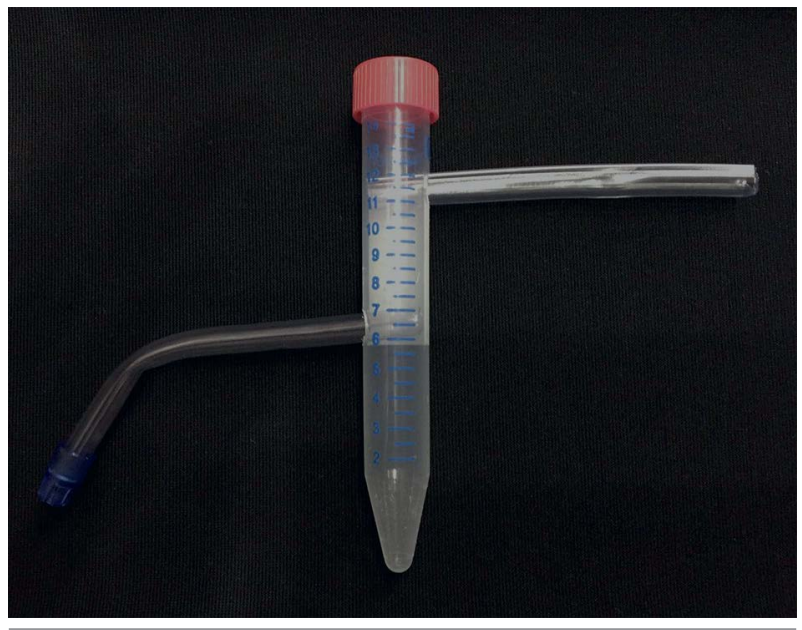

Figure 1. Special disposable sialometer according to Serratine et al. ${ }^{30}$ the following measures were conducted soon after the initial collection.

The $\mathrm{pH}$ was evaluated using a digital $\mathrm{pH}$ meter, Benchtop-Q400AS (Quimis scientific apparatus, São Paulo, SP, Brazil). The $\mathrm{pH}$ of the saliva was categorized as follows: critical $\mathrm{pH}$ enamel demineralization: below 5.5, acidic pH: 5.5 to 6.0 and normal pH: 6 to $7 .^{32}$

The salivary buffer capacity was determined by adding $3 \mathrm{~mL}$ of a solution of $\mathrm{HCl}$ (hydrochloric acid) to $5 \mathrm{mmol}$ at a rate of $1 \mathrm{~mL}$ of total unaltered saliva. After homogenization of total saliva in a Vortex agitator (AP56, Phoenix Luferco) and after $5 \mathrm{~min}$ for $\mathrm{CO}_{2}$ to escape from the saliva in an open vial, the $\mathrm{pH}$ of the $\mathrm{HCl}$-saliva mixture was determined. The reading of the test to check the buffering capacity of saliva of the patients was categorized as follows: low buffering capacity: $\mathrm{pH}$ below 4; limited buffering capacity: 4.0 to 5.0; and normal $\mathrm{pH}$ buffering capacity: 5.0 to $7.0 \mathrm{pH} .^{32}$

Count of Colony Forming Units (CFU/mL)

For the culture of $S$. mutans, $25 \mu \mathrm{L}$ aliquots of each dilution in saliva were inoculated in agar culture medium Mitis Salivarius Bacitracin (MSB), containing bacitracin (Sigma) (0.2 IU/mL MSB), ${ }^{33}$ and incubated for 48 hours in $10 \% \mathrm{CO}_{2}$ at $37^{\circ} \mathrm{C}$ (Coler Parmer, USA). Following the calculation of $\mathrm{CFU} / \mathrm{mL}$, the data were subsequently classified into the following categories: low: $<10^{5}$, average: $10^{5}$ to $10^{6}$, and high: $>10^{6}$.

\section{Statistical analysis of the results}

Descriptive statistics were calculated for all data, including the summary measures, percentage, mean and standard deviation. The Spearman correlation coefficient was used to verify the correlation between the experience of caries (DMF-T) and the variables studied. The associations between the salivary flow and use of controlled drugs were analyzed by using the Fisher exact test. The significance level adopted was $5 \%(p=0.05)$.

\section{Results}

In this study, we attempted to relate possible causative factors that could interfere with the caries experience in individuals with FXS. Table 1 shows that the average DMF-T of the patients was 5.5 teeth affected by caries disease. The average value of the salivary $\mathrm{pH}$ was 7.04 , which is considered within 
Table 1. Description of the average, minimum and maximum values found for the variables studied in individuals with FXS.

\begin{tabular}{|c|c|c|c|c|}
\hline Variable & Minimum & Maximum & Average & $\begin{array}{l}\text { Standard } \\
\text { deviation }\end{array}$ \\
\hline Age & 12.00 & 25.00 & 17.34 & 5.60 \\
\hline $\begin{array}{l}\text { Oral hygiene- } \\
\text { visible biofilm }\end{array}$ & 0.00 & 5.00 & 3.26 & 1.63 \\
\hline DMF-T & 0.00 & 18.00 & 5.52 & 4.36 \\
\hline $\begin{array}{l}\text { Salivary flow } \\
(\mathrm{mL} / \mathrm{min})\end{array}$ & 0.1 & 1.1 & 0.33 & 0.32 \\
\hline Salivary pH & 5.80 & 8.40 & 7.04 & 0.67 \\
\hline Buffering capacity & 3.00 & 6.00 & 4.40 & 0.87 \\
\hline $\begin{array}{l}\text { Socioeconomic } \\
\text { status }\end{array}$ & 3.00 & 6.00 & 3.49 & 1.04 \\
\hline $\mathrm{CFU} / \mathrm{mL}$ & $1.7 \times 10^{2}$ & $2.3 \times 10^{11}$ & $1.5 \times 10^{10}$ & $5.0 \times 10^{10}$ \\
\hline
\end{tabular}

normal parameters. The buffering capacity, also a risk factor for the development of dental caries, averaged 4.40 , which included both limited or reduced statuses.

Table 2 shows that $78.3 \%$ of the studied patients were male, and $73.9 \%$ used some type of controlled drug. In the description of the variable 'socioeconomic status', only $13 \%$ of the patients were found to be in the middle class, and these patients presented with the lowest index of dental caries (DMF-T $=0.6)$. Regarding salivary characteristics, $78.3 \%$ of the sample showed a decreased salivary flow. The buffering capacity was considered normal in just $26.1 \%$ of patients with FXS. The quality of oral hygiene performed was deficient in $60.9 \%$. Only 4 of 23 volunteers were free of caries experience, DMF-T index $=0$. Regarding the presence of $S$. mutans $(\mathrm{CFU} / \mathrm{mL})$, most $(60.9 \%)$ were considered to be between the medium- and high-count groups for $S$. mutans.

In Table 3, the salivary parameters analyzed and the socioeconomic patterns show negative correlations with caries experience: the smaller the salivary flow, $\mathrm{pH}$ and buffering capacity were, the greater the index of caries in patients evaluated. The variables of age, use of medicines, amount of biofilm present and $\mathrm{CFU} / \mathrm{mL}$ of $S$. mutans are positively correlated with caries experience, such that as the values of the variables mentioned above increase, the rate of tooth decay increases. All these factors were considered to have statistically significant relationships.
Table 2. Distribution and description of the sample according to caries experience and studied variables of individuals with FXS.

\begin{tabular}{|c|c|c|c|c|}
\hline Variable & Category & $D M F-t$ & Frequency & Percentage \\
\hline \multirow{3}{*}{ Sex } & $\mathrm{F}$ & 6.2 & 5 & $21.7 \%$ \\
\hline & & & & \\
\hline & M & 5.3 & 18 & $78.3 \%$ \\
\hline \multirow{2}{*}{$\begin{array}{l}\text { Use of } \\
\text { controlled } \\
\text { drugs }\end{array}$} & Yes & 6.7 & 17 & $73.9 \%$ \\
\hline & No & 2 & 6 & $26.1 \%$ \\
\hline \multirow{3}{*}{$\begin{array}{l}\text { Socioeconomic } \\
\text { status }\end{array}$} & Low & 8.1 & 11 & $47.8 \%$ \\
\hline & $\begin{array}{l}\text { Medium- } \\
\text { Low }\end{array}$ & 3.8 & 9 & $39.1 \%$ \\
\hline & Medium & 0.6 & 3 & $13.0 \%$ \\
\hline \multirow{2}{*}{$\begin{array}{l}\text { Salivary flow } \\
\text { (mL/min) }\end{array}$} & $\begin{array}{l}\text { Decreased } \\
\quad(<0.3)\end{array}$ & 6.9 & 18 & $78.3 \%$ \\
\hline & $\begin{array}{l}\text { Normal } \\
(>0.3)\end{array}$ & 2.0 & 5 & $21.7 \%$ \\
\hline \multirow{3}{*}{ Salivary pH } & $\begin{array}{l}\text { Acidic } \\
(5.5-6)\end{array}$ & 11.2 & 4 & $17.4 \%$ \\
\hline & $\begin{array}{c}\text { Normal } \\
(6-7)\end{array}$ & 4.5 & 17 & $73.9 \%$ \\
\hline & $\begin{array}{l}\text { Alkaline } \\
(>8)\end{array}$ & 2.0 & 2 & $8.7 \%$ \\
\hline \multirow{3}{*}{$\begin{array}{l}\text { Buffering } \\
\text { capacity }\end{array}$} & $\begin{array}{l}\text { Low } \\
(<4)\end{array}$ & 8.2 & 9 & $39.1 \%$ \\
\hline & $\begin{array}{l}\text { Limited } \\
(4-5)\end{array}$ & 5.1 & 8 & $34.8 \%$ \\
\hline & $\begin{array}{l}\text { Normal } \\
(>5)\end{array}$ & 2.0 & 6 & $26.1 \%$ \\
\hline \multirow{3}{*}{ Oral hygiene } & $\begin{array}{c}\text { Handicapped } \\
\text { (3-5) }\end{array}$ & 7.5 & 14 & $60.9 \%$ \\
\hline & $\begin{array}{l}\text { Satisfactory } \\
(1-2)\end{array}$ & 2.6 & 8 & $34.8 \%$ \\
\hline & $\begin{array}{l}\text { Excellent } \\
\text { (0) }\end{array}$ & 0 & 1 & $4.3 \%$ \\
\hline \multirow[t]{2}{*}{ DMF-T } & $\begin{array}{l}\text { Zero } \\
(0)\end{array}$ & 0 & 4 & $17.4 \%$ \\
\hline & $\geq 1$ & 5.5 & 19 & $82.6 \%$ \\
\hline \multirow{3}{*}{$\mathrm{CFU} / \mathrm{mL}$} & $\begin{array}{c}\text { Low } \\
\left(<10^{5}\right)\end{array}$ & 3.2 & 9 & $39.1 \%$ \\
\hline & $\begin{array}{l}\text { Medium } \\
\left(10^{5}-10^{6}\right)\end{array}$ & 4.5 & 2 & $8.7 \%$ \\
\hline & $\begin{array}{l}\text { High } \\
\left(>10^{6}\right)\end{array}$ & 7.8 & 12 & $52.2 \%$ \\
\hline
\end{tabular}

Table 4 shows the frequency distribution of the use of controlled drugs; $73.90 \%$ of the patients in the research had used some type of controlled medication, and only 6 patients in the sample had not used medication. 
The results of Table 5 show that the salivary flow was significantly lower in patients who use controlled drugs for FXS ( $\mathrm{p}<0.0001)$ : the salivary flow was decreased, i.e., below $0.3 \mathrm{~mL} / \mathrm{min}$, in $100 \%$ of the patients who used the controlled drugs.

Table 3. Correlation $(r)$ between experience of dental caries and salivary $\mathrm{pH}$, flow, buffering capacity, age, medications, socioeconomic level, oral hygiene and CFU/mL.

\begin{tabular}{lcc}
\hline Variable X DMF-T & $r$ & $p^{*}$ \\
\hline Salivary flow (mL/min) & -0.503 & 0.015 \\
Salivary pH & -0.540 & 0.008 \\
Buffering capacity & -0.663 & 0.001 \\
Age & 0.607 & 0.002 \\
Use of controlled drugs & 0.601 & 0.002 \\
Socioeconomic status & -0.564 & -0.005 \\
Oral hygiene-visible Biofilm & 0.851 & 0.000 \\
CFU/mL & 0.621 & 0.002 \\
\hline
\end{tabular}

*Statistically significant difference $(p<0.05)$.

Table 4. Frequency of use of controlled psychotropic drugs by FXS individuals.

\begin{tabular}{lcc}
\hline Drugs & Frequency & $\begin{array}{c}\text { Percentage } \\
(\%)\end{array}$ \\
\hline Anticonvulsant & 5 & 21.7 \\
Anticonvulsant + Anxiolytic / Sedative & 2 & 8.7 \\
Antipsychotic + Stimulants & 4 & 17.4 \\
Antipsychotic + Anxiolytic / Sedative & 4 & 17.4 \\
$\begin{array}{l}\text { Antipsychotic + Anticonvulsant + } \\
\text { Stimulants }\end{array}$ & 1 & 4.4 \\
$\begin{array}{l}\text { Antipsychotic + Anticonvulsants + } \\
\text { Anxiolytic / Sedative }\end{array}$ & 1 & 4.4 \\
\begin{tabular}{l} 
Does not take any medication \\
\hline
\end{tabular} & 6 & 26.1 \\
\hline
\end{tabular}

Table 5. Association between the use of controlled drugs and salivary flow $(p<0.0001)$.

\begin{tabular}{lcc}
\hline \multirow{2}{*}{ Salivary flow } & \multicolumn{2}{c}{ Use of controlled drugs } \\
\cline { 2 - 3 } & No & Yes \\
\hline Low & $1(17 \%)$ & $17(100 \%)$ \\
Normal & $5(83 \%)$ & $0(0 \%)$ \\
Total & $6(100 \%)$ & $17(100 \%)$ \\
\hline
\end{tabular}

\section{Discussion}

Because there have been only a few studies concerning the oral health condition of patients with FXS and considering the necessity and importance of planning dental care for this specific population, this study aimed to identify the variables that negatively influence the oral health of these patients.

Patients aged 12 to 25 years old were surveyed. As the age of the individuals surveyed increased, caries experience also increased (Table 1). This result was also found in the study of Shellhart et al..$^{12}$ who also evaluated caries experience in FXS. This reinforces the need to plan and execute measures for the prevention and control of oral diseases from an early age in addition to requiring the establishment of protocols for use in reducing caries. ${ }^{34,35}$

This study analyzed 23 patients, 18 males and 5 females, demonstrating that the prevalence and penetrance of FXS is always greater in males, according to the study of Ridaura-Ruiz et al. ${ }^{6}$, which reports a prevalence of one in every 4,000 men and one in every $6,000-8,000$ women. It is not uncommon to find women with the syndrome; however, women are clinically less affected by the characteristics of FXS ${ }^{6}$ This result was also verified in the sample evaluated because the women presented with a lesser degree of disability from FXS.

The presence of dental biofilm confirms the condition of poor oral hygiene, and the higher the amount of visible biofilm on the surfaces of teeth, the higher the DMF-T values were, showing that oral hygiene habits were not established (Table 1). Amaral et al..$^{10}$ observed a prevalence of $93 \%$ for the presence of biofilm and a prevalence of $81 \%$ for the presence of gingivitis in patients with FXS and reported that the lack of cooperation of these patients with those caregivers responsible for performing oral hygiene is an aggravating factor for the low quality of hygiene and oral health.

The salivary characteristics are relevant factors in the maintenance of oral health, considering the importance of saliva as a mechanical cleaning agent, including its action on reducing enamel solubility through the deposition of calcium, phosphate and fluoride. Furthermore, tampon function is responsible for neutralizing the acids produced by cariogenic micro-organisms. ${ }^{21}$ In the group of FXS patients studied, $78 \%$ showed decreased salivary flow speed, 
and $74 \%$ had a low to limited saliva buffering capacity; however, the salivary $\mathrm{pH}$ appeared normal in $74 \%$ of the participants, with an average of 7.04 (Table 2).

The salivary parameters showed a significantly negative correlation with DMF-T $(\mathrm{p}<0.05)$ (Table 3), corroborating the data found in the literature and reinforcing the presence of a correlation between salivary parameters and tooth decay in different patient groups. ${ }^{15,16,17,18,19,20,21}$ However, the literature is not unanimous in asserting the presence of correlation between salivary characteristics and the DMF-T index, confirming the complexity of the etiology of caries disease and supporting the argument that caries indices should be analyzed in conjunction with other risk factors, such as hygiene, diet, socioeconomic status, and the use of fluoride. ${ }^{36}$

The unsatisfactory hygiene index found in $61 \%$ of the patients (Table 2), associated with the indications of a positive and statistically significant correlation $(\mathrm{p}<0.05)$ between the abundance $(\mathrm{CFU} / \mathrm{mL})$ of $S$. mutans and the DMF-T index, supports the hypothesis that the larger numbers of micro-organisms in the biofilms are important etiological agents in the establishment and development of dental caries. In this context, it is important for the planning and implementation of preventive programs for the population of patients with FXS because invasive treatments become complex in these patients, due to the presence of behavioral and difficulty barriers. ${ }^{37}$ However, there is disagreement among researchers regarding the existence of a relationship between the abundance of $S$. mutans in dental biofilm and the development of caries disease because there are cases of populations with a high count of $S$. mutans that do not present with caries or have a low caries index, ${ }^{37}$ reaffirming the multifactorial nature of this disease.

Use of psychotropic drugs in individuals presenting FSX is common due to the presence of intellectual deficits, convulsive seizures, autistic behavior, anxiety disorder, attention deficit hyperactivity disorder, impulsivity, mood instability and aggressiveness. ${ }^{27,38,39}$ Most of the volunteers in this study (73\%) took somekind of controlled medications, such as anticonvulsants, anxiolytics, sedatives, stimulants, or antipsychotics (Table 4). Kaur et al..$^{39}$ evaluated children under psychiatric treatment making chronic use of psychotropic drugs. The authors observed xerostomia in $60 \%$ of the volunteers, correlating it with dental caries. In this study, all FXS patients who used psychotropic drugs presented decreased salivary flow (Table 5). Moreover, a positive correlation was found between the use of controlled medication and the prevalence of dental caries, suggesting a relationship between the chronic use of psychotropic drugs and decreased salivation.

The prescription and use of psychotropic drugs has been progressively increasing among children and adolescents due to special or behavioral conditions. ${ }^{38,39}$ This should be carefully considered mainly in patients with special needs, as there are other aggravating factors influencing their oral health quality. However, few studies have evaluated the prevalence of xerostomia in children and adolescents who use chronic psychotropic medications.

In this study, the correlation between an individual's socioeconomic status and caries prevalence was statistically significant, since $63.6 \%$ of patients with low socioeconomic status were classified as having higher prevalence of caries than other patients, whereas most patients who were classified as middle class were free of caries (Table 2). In a published study, researchers evaluated 41 children with special needs, observed that $66 \%$ of cases belonged to families of low socioeconomic status and realized that most of those children had high caries experience. ${ }^{40} \mathrm{~A}$ similar result was found in a study that described the incidence of caries among children and adolescents with cerebral palsy, which concluded that participants whose family and caregivers had more schooling showed a significantly lower incidence of dental caries, ${ }^{22}$ these data corroborate and reaffirm the findings of the present study.

One of the limitations of this study is the difficulty in managing the dental approach for these patients, regarding the difficulty of dental physical examination and collecting saliva samples, since most patients are hyperactive and autistic and have cognitive deficits. It is important for dental surgeons to have knowledge of the oral conditions commonly found in patients with FXS and its relation to an increase in the oral health risk for this condition, justifying the importance of the establishment of prevention and intervention protocols as soon as possible to avoid more complex treatments in this population. 


\section{Conclusion}

The individuals carrying FXS presented with decreased salivary flow and buffering capacity. The salivary flow was significantly lower in the volunteers

\section{References}

1. Sireteanu A, Rusu C. [Diagnostic testing in fragile $X$ syndrome. Rev Med Chir Soc Med Nat lasi. 2006;110:968-71. Romanian.

2. Neri G, Genuardi M. Genetica umana e medica. 3rd ed. Milano: Elsevier-Masson; 2014.

3. Saldarriaga W, Tassone F, González-Teshima LY, ForeroForero JV, Ayala-Zapata S, Hagerman R. Fragile X syndrome. Colomb Med (Cali). 2014;45(4):190-8.

4. Hagerman PJ, Greco CM, Hagerman RJ. A cerebellar tremor/ataxia syndrome among fragile $X$ prermutation carriers. Cytogenet Genome Res. 2003;100(1-4):206-12. https://doi.org/10.1159/000072856

5. Loesch D, Hagerman R. Unstable mutations in the FMR1 gene and the phenotypes. Adv Exp Med Biol. 2012;769:78-114. https://doi.org/10.1007/978-1-4614-5434-2_6

6. Ridaura-Ruiz L, Quinteros-Borgarello M, Berini-Aytés L, GayEscoda C. Fragile X-syndrome: literature review and report of two cases. Med Oral Patol Oral Cir Bucal. 2009;14(9):e434-9.

7. Wadell PM, Hagerman RJ, HessI DR. Fragile X syndrome: psychiatric manifestations, evaluation and emerging therapies. Curr Psychiatry Rev. 2013;9(1):53-8. https://doi.org/10.2174/157340013805289644

8. Oakes A, Thurman AJ, McDuffie A, Bullard LM, Hagerman RJ, Abbeduto $L$. Characterising repetitive behaviours in young boys with fragile $X$ syndrome. J Intellect Disabil Res. 2016;60(1):54-67. https://doi.org/10.1111/jir.12234

9. Chonchaiya W, Schneider A, Hagerman RJ. Fragile X: a family of disorders. Adv Pediatr. 2009;56(1):165-86. https://doi.org/10.1016/i.yapd.2009.08.008

10. Amaral CO, Solitto KC, Santos TM, Parizi AG, Oliveira A, Straioto FG. Características físicas e bucais em pacientes portadores da Síndrome do X-Frágil. Rev Assoc Paul Cir Dent. 2012;66:128-34.

11. Silva LCP, Cruz RA. Odontologia para pacientes com necessidades especiais: protocolos para o atendimento clínico. São Paulo: Santos; 2009.

12. Shellhart WC, Casamassimo PS, Hagerman RJ, Belanger GK, Opitz JM, Reynolds JF. Oral findings in fragile X syndrome. Am J Med Genet. 1986;23(1-2):179-87. https://doi. org/10.1002/ajmg.1320230112

13. Miamoto CB, Ramos-Jorge ML, Pereira LJ, Paiva SM, Pordeus IA, Marques LS. Severity of malocclusion in patients with cerebral palsy: determinant factors. Am J Orthod Dentofacial Orthop. 2010;138(4):el-5. https://doi.org/10.1016/i.ajodo.2010.03.025 who used psychotropic drugs. Correlations were observed between the experience of caries and changes in salivary parameters, poor oral hygiene, lower socioeconomic status and increased abundance of $S$. mutans in saliva.

14. Gallarreta FWM, Turssi CP, Palma-Dibb RG, Serra MC. Histórico de saúde: atenção a condições sistêmicas e suas implicações, sobretudo nos fatores de risco de cárie. Rev Odonto Cienc. 2008;23(2):192-6.

15. Zhou Q, Bai J, Qin M. [Relationship between cariogenic microbe, salivary buffer capacity and early childhood caries]. Zhonghua Kou Qiang Yi Xue Za Zhi. 2007;42(10):581-4. Chinese.

16. Ou-Yang LW, Chang PC, Tsai Al, Jaing TH, Lin SY. Salivary microbial counts and buffer capacity in children with acute lymphoblastic leukemia. Pediatr Dent. 2010;32(3):218-22.

17. Subramaniam P, Babu KL, Rodriguez A. Relation of salivary risk factors to dental caries in children with cerebral palsy. J Clin Pediatr Dent. 2010;34(4):355-60. https://doi.org/10.17796/jcpd.34.4.5750n50504180j61

18. Filipi K, Halackova Z, Filipi V. Oral health status, salivary factors and microbial analysis in patients with active gastrooesophageal reflux disease. Int Dent J. 2011;61(4):231-7. https://doi.org/10.1111/j.1875-595X.2011.00063.x

19. Kaur A, Kwatra KS, Kamboj P. Evaluation of nonmicrobial salivary caries activity parameters and salivary biochemical indicators in predicting dental caries. J Indian Soc Pedod Prev Dent. 2012;30(3):212-7. https://doi.org/10.4103/0970-4388.105013

20. Aranibar Quiroz EM, Alstad T, Campus G, Birkhed D, Lingström P. Relationship between plaque $\mathrm{pH}$ and different caries-associated variables in a group of adolescents with varying caries prevalence. Caries Res. 2014;48(2):147-53. https://doi.org/10.1159/000355614

21. Animireddy D, Reddy Bekkem VT, Vallala P, Kotha SB, Ankireddy S, Mohammad N. Evaluation of $\mathrm{pH}$, buffering capacity, viscosity and flow rate levels of saliva in caries-free, minimal caries and nursing caries children: an in vivo study. Contemp Clin Dent. 2014;5(3):324-8. https://doi.org/10.4103/0976-237X.137931

22. Camargo MAF, Frias AC, Antunes JL. The incidence of dental caries in children and adolescents who have cerebral palsy and are participating in a dental program in Brazil. Spec Care Dentist. 2011;31(6):210-5. https://doi.org/10.1111/j.1754-4505.2011.00213.x

23. Saban A, Ridic O, Karamehic J, Saban O, Delic-Sarac M, Dzananovic N, et al. Assessments of the socioeconomic status and diet on the prevalence of dental caries at school children in central bosnian canton. Mater Sociomed. 2014;26(5):309-12. https://doi.org/10.5455/msm.2014.26.309-312 
24. Costa VP, Goettems ML, de Oliveira LJ, Tarquinio SB, Torriani DD, Correa MB, et al. Nonuse of dental service by schoolchildren in Southern Brazil: impact of socioeconomics, behavioral and clinical factors. Int J Public Health. 2015;60(4):411-6. https://doi.org/10.1007/s00038-015-0670-2

25. Ferreira-Júnior OM, Freire MC, Moreira RS, Costa LR. Contextual and individual determinants of dental pain in preschool children. Community Dent Oral Epidemiol. 2015;43(4):349-56. https://doi.org/10.1111/cdoe.12159

26. Graciano M. Critérios de avaliação para classificação sócio-econômica. Serv Soc Soc. 1980;1:81-103.

27. Organização Mundial da Saúde. Levantamentos básicos em saúde bucal. 4a ed. São Paulo: Santos; 1999.

28. Ribeiro AA, Portela M, Souza IP. [Relation between biofilm, caries activity and gingivitis in HIV + children]. Pesqui Odontol Bras. 2002;16(2):144-50. Portuguese. https://doi.org/10.1590/S1517-74912002000200009

29. Navazesh M, Christensen CM. A comparison of whole mouth resting and stimulated salivary measurement procedures. J Dent Res. 1982;61(10):1158-62. https://doi.org/10.1177/00220345820610100901

30. Serratine ACP, Silva MRM. Evaluation of the effectiveness of a sialometer Developed to measure salivary flow rate in children. Pesq Bras Odontoped Clin Integr. 2008;8(1):75-9. http://dx.doi.org/10.4034/pboci.v8i1.243

31. Cunha KS, Menezes RE, Luna EB, Almeida LM, Pontes RR, Almeida $\mathrm{PN}$ et al. High prevalence of hyposalivation in individuals with neurofibromatosis 1: a case-control study controle. Orphanet J Dis Rare. 2015;10(1):1-4. https://doi.org/10.1186/s13023-015-0239-4

32. Krasse B. Biological factors as indicators of future caries. Int Dent J. 1988;38(4):219-25.
33. Gold OG, Jordan HV, Van Houte J. A selective medium for Streptococcus mutans. Arch Oral Biol. 1973;18(11):1357-64. https://doi.org/10.1016/0003-9969(73)90109-X

34. Gudkina J, Brinkmane A. The impact of salivary mutans streptococci and sugar consumption on caries experience in 6-year olds and 12-year olds in Riga. Stomatologija. 2010;12(2):56-9.

35. Pannu P, Gambhir R, Sujlana A. Correlation between the salivary Streptococcus mutans levels and dental caries experience in adult population of Chandigarh, India. Eur J Dent. 2013;7(2):191-5. https://doi.org/10.4103/1305-7456.110169

36. Bretas $L P$, Roch ME, Vieira MS, Rodrigues AC. Flow rate and buffering capacity of the saliva as indicators of the susceptibility to caries disease. Pesq Bras Odontoped Clin Integr. 2008;8:289-93. https://doi.org/10.4034/1519.0501.2008.0083.0006

37. Beighton D. The complex oral microflora of high-risk individuals and groups and its role in the caries process. Community Dent Oral Epidemiol. 2005;33(4):248-55. https://doi.org/10.1111/i.1600-0528.2005.00232.x

38. Friedlander AH, Yagiela JA, Paterno VI, Mahler ME. The pathophysiology, medical management and dental implications of fragile X, Rett, and Prader-Willi syndromes. J Calif Dent Assoc. 2003;31(9):693-702.

39. Kaur M, Himadi E, Donald LC. Prevalence of xerostomia in an adolescent inpatient psychiatric clinic: a preliminary study. Spec Care Dentist. 2016;36(2):60-5. https://doi.org/10.1111/scd.12154

40. Guerreiro PO, Garcias GL. [Oral health conditions diagnostic in cerebral palsy individuals of Pelotas, Rio Grande do Sul State, Brazil. Cien Saúde Colet. 2009;14(5):1939-46. Portuguese. https://doi.org/10.1590/S1413-81232009000500036 